\title{
NOTES ON THE MODE OF LIFE OF THE TELLINIDAE (LAMELLIBRANCHIA)
}

\author{
By N. A. Holme \\ The Plymouth Laboratory
}

(Text-figs. I-3)

Ten species of Tellinidae occur in British waters, belonging to the genera Arcopagia, Tellina, Gastrana and Macoma (Winckworth, 1932, 1951). This paper is concerned only with Arcopagia crassa, and the commoner species of Tellina: $T$. squalida, $T$. tenuis, $T$. fabula, $T$. donacina and $T$. pygmaea. These species burrow in sands, muds or gravels, maintaining connexion with the overlying water through their long and extensile siphons. Some account of the habitat of individual species is given by Yonge (1949).

The majority of burrowing lamellibranchs occupy a more-or-less vertical position when buried, but a few (e.g. Cochlodesma, see Allen, 1958) lie horizontally beneath the surface. While studying dispersal in a population of $T$. tenuis (Holme, 1950), it was noticed that the majority of specimens excavated at low tide lay on their sides, but it was not at the time appreciated that they always lay with one side, the right, uppermost. Yonge (I949) assumed that members of the Tellinidae occupy a vertical position when buried, but he is of the opinion (personal communication) that T. tenuis makes considerable vertical movements in the sand according to the state of the tide, so that the position in which it is found at low tide may be rather different from that when covered by water.

Both MacGinitie (1935) and Fitch (1953) record that the North American shore clam Macoma nasuta lies on its left side, the posterior end of the shell, which is curved to the right, being inclined upwards, so that it seemed possible that other members of the Tellinidae might show similar habits.

Observations on the habits of the Tellinidae have been made as follows: (a) on the position of animals dug up at low tide on the shore, $(b)$ on the method of burrowing, $(c)$ on the shape of the valves.

\section{POSITION OF ANIMALS ON THE SHORE}

The only species at all common on the shore are Tellina tenuis, T. fabula, and T. squalida (in south-west England). Careful excavation, or the chance exposure of a specimen when digging, has shown that all three species lie on their left sides, usually within about $30^{\circ}$ of the horizontal. Of twenty-two specimens of $T$. tenuis excavated in the Exe estuary, twenty-one lay on the 
left side, and one on its right side, but fewer observations have been made on the other two species, which were, however, invariably found on their left sides.

The normal habit of these species is shown in Fig. I, but it should be noted that the disposition of the siphons is not based on any new observations. Yonge (1949) describes the long inhalant siphon of T. tenuis the tip of which lies along the surface of the sand. He figures the exhalant siphon as just projecting above the surface, but states that 'the exhalant siphon was never observed to project above the sand although it must be continually open to allow the through passage of large quantities of water which enter the other siphon'.

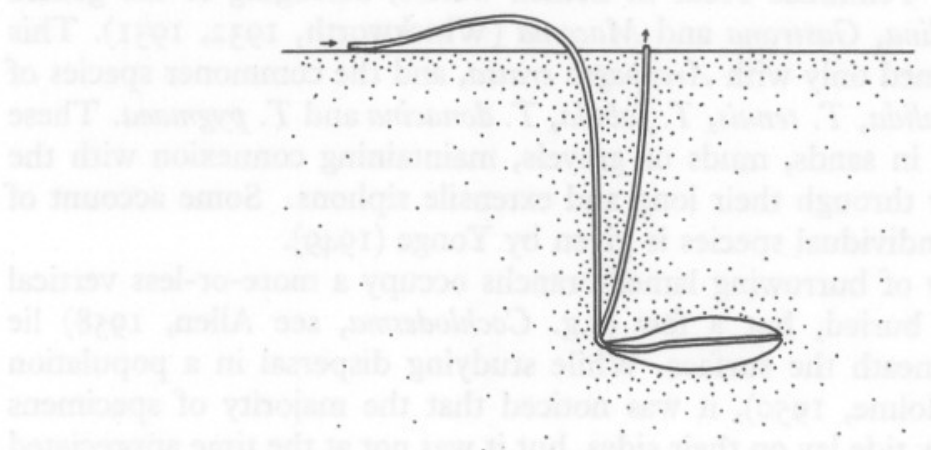

Fig. I. Diagram of Tellina squalida lying on its left side in the sand. The disposition of the siphons is hypothetical, see text. $\times \frac{1}{2}$.

In Arcopagia crassa, the only species I have observed in detail, the exhalant siphon has never been seen at the surface, and the inhalant siphon tends to project upwards rather than lie along the surface. If such observations in the laboratory are a guide to the natural habit, they suggest that the normal position of the siphons in other Tellinidae requires further observation. Possibly Arcopagia disposes its inhalant siphon so as to filter as a suspension rather than a deposit feeder, and it may be that the exhalant siphon is not normally extended to the surface. The gravel in which it lives is quite permeable, so that an exhalant stream could be discharged well below the surface of the gravel. This recalls the habit of Macoma nasuta described by MacGinitie (1935) and figured in MacGinitie \& MacGinitie (1949).

\section{OBSERVATIONS ON BURROWING UNDER WATER}

Arcopagia crassa. Specimens were placed on the surface of shell gravel and their burrowing observed. Specimens lying on their left side on the surface (the normal position when buried) would after a time cautiously 
extend the triangular tongue-like foot, which was then directed downwards into the gravel (Fig. 2). Burrowing movements follow the normal pattern, the foot being extended and then thickened and contracted to draw the shell into the substratum. When a grip was obtained in the gravel the posterior end of the shell was raised by successive contractions to about $45^{\circ}$ to the horizontal, and the animal then burrowed obliquely into the gravel at this angle, the ligament axis being approximately horizontal (Fig. 3).

Specimens lying on their right side started to burrow in the same way, but successive contractions of the foot raised the shell up to and just beyond the vertical, the shell being partially turned over before it entered the gravel. Subsequent contractions of the foot continued the turning of the shell, so that it finally disappeared below the surface at an angle of about $45^{\circ}$, with the right side uppermost. Of several dozen specimens allowed to burrow and subsequently excavated, not one had its left valve uppermost. While a few were nearly vertical, the majority, particularly those $7 \mathrm{~cm}$ or more below the surface, had the right valve uppermost.

The shell of Arcopagia crassa is rather heavy, and some effort is required to turn it over. In T. tenuis, $T$. squalida and $T$. donacina the animal is smaller and the shell lighter and thinner. In these the shell, of those placed on their right sides, was not raised beyond the vertical before it entered the substratum. Successive burrowing movements turned the shell over while it was entering the soil so that when it disappeared from sight it might have only just reached the vertical position. Specimens placed on their left sides burrowed obliquely, as in Arcopagia. Observation of these species was made on the shore, and, when specimens were dug up a few minutes later, the right side was always uppermost. Only one or two specimens of $T$. donacina were observed, but quite a number of observations were made on the other two species.

\section{THE SHAPE OF THE VALVES}

The majority of the Tellinidae shows some asymmetry between the two valves, and in T. fabula the right valve exhibits oblique striae which are absent in the left valve. In some the posterior ends are inclined to one side: a marked inclination to the right is shown in the American Macoma nasuta, and the same tendency is shown, to a lesser degree, in some British species. In $T$. squalida the posterior end is somewhat produced, and both valves show a slight though distinct curvature to the right (Fig. I), and a similar but lesser curvature is shown in T. donacina, T. fabula and T. tenuis. In Arcopagia crassa the right valve is a little deeper and more convex than the left. The posterior end, if anything, points a little to the left (Fig. 3) and there is a double fold radiating towards the postero-ventral margin of the shell. A rather similar fold occurs in $T$. pygmaea. In these two last species, therefore, the shell gives no indication of the animal's habits. 

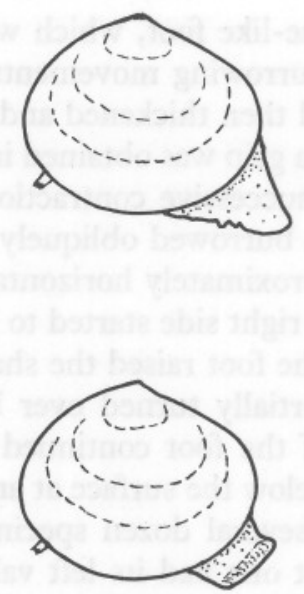

Fig. 2. Arcopagia crassa, showing burrowing movements of foot. One siphon is just protruding from the shell. $\times \frac{1}{2}$.
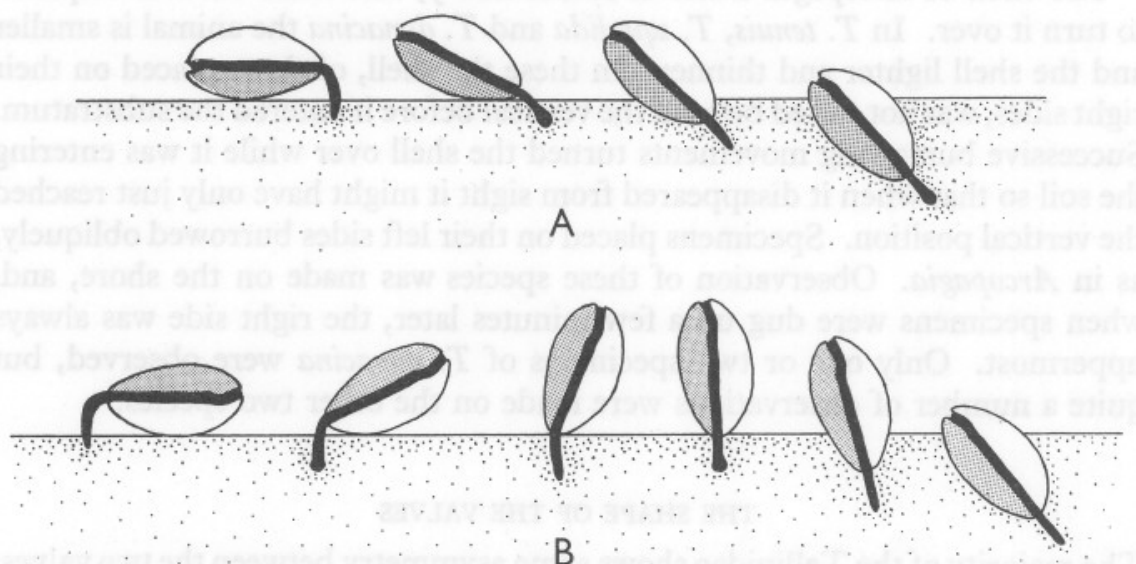

B

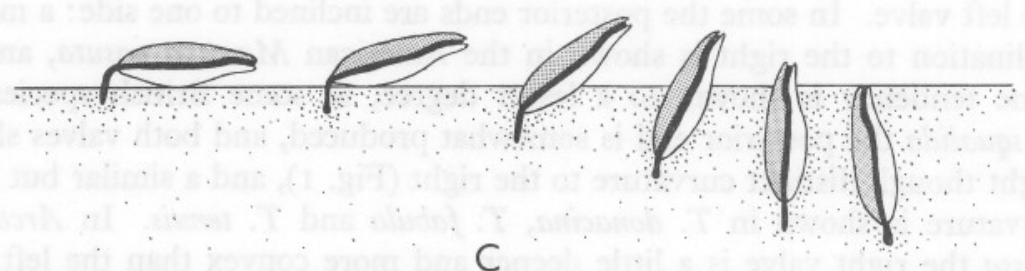

Fig. 3. Burrowing of tellinids, viewed from the ventral side. The left valve is stippled in each instance. $\times \frac{2}{5}$. A. Arcopagia crassa placed on its left side burrows obliquely at about $45^{\circ}$. B. A. crassa placed on its right side turns over before entering the sand. c. Tellina squalida placed on its right side turns over as it burrows down into the sand. Placed on its left side it burrows as in Arcopagia crassa (A). 
There does not appear to be any asymmetry of the internal organs connected with the mode of life.

The habit of lying on one side would increase the ease with which a burrowing bivalve could make horizontal migrations. In deposit-feeding forms such as the Tellinidae this might allow a fuller exploitation of the soil surface by the siphons through the dispersal of individuals away from one another. In Tellina tenuis populations on the Exe such movements result in a very evenly distributed or 'overdispersed' population (Holme, I950); alternatively the horizontal migrations may be of use in finding more favourable areas or for migrations up and down the shore.

\section{SUMMARY}

Evidence from animals dug up on the shore, from observations on burrowing, or from shell shape indicates that the following species normally lie below the surface with their right valve uppermost: Tellina squalida, $T$. tenuis, T. fabula, T. donacina, and Arcopagia crassa. Information on the habits of the remaining Tellinidae has not been obtained.

Animals placed on the surface of the soil with the left side up turn themselves over as they burrow. In Arcopagia the shell is turned over beyond the vertical before the animal enters the substratum, but in the remaining species studied the shell is gradually turned over so that it disappears below the surface almost vertically and subsequently completes the turning movement beneath the surface.

The disposition of the siphons of Arcopagia may differ somewhat from that of $T$. tenuis as described by Yonge, and there is a need for further observation on the siphons of the other species.

\section{REFERENCES}

Allen, J. A., 1958. Observations on Cochlodesma praetenue (Pulteney) (Eulamellibranchia). F. mar. biol. Ass. U.K., Vol. 37, pp. 97-II2.

FItch, J. E., I953. Common marine bivalves of California. Fish. Bull. Sacramento, No. 90, IO2 pp.

Holme, N. A., I950. Population-dispersion in Tellina tenuis da Costa. F. mar. biol. Ass. U.K., Vol. 29, pp. 267-80.

MacGinitie, G. E., I935. Ecological aspects of a California marine estuary. Amer. Midl. Nat., Vol. I6, pp. 629-765.

MacGinitie, G. E. \& MacGinitie, N., 1949. Natural History of Marine Animals, 473 pp. New York: McGraw-Hill.

WINCKWORTH, R., I932. The British marine Mollusca. f. Conch., Vol. I9, pp. 21 I52.

- 1951. A list of the marine Mollusca of the British Isles: additions and corrections. F. Conch., Vol. 23, pp. 13I-4.

Yonge, C. M., I949. On the structure and adaptations of the Tellinacea, deposit feeding Eulamellibranchia. Phil. Trans., B, Vol. 234, pp. 29-76. 